Global Nest: the Int. J. Vol 1, No 1, pp 55-62, 1999

Copyright@ 1998 GLOBAL NEST

Printed in Greece. All rights reserved

\title{
PHOTOCATALYTIC TREATMENT OF OLIVE MILLING WASTE WATER:
XIDATION OF PROTOCATECHUIC ACID OF OLIVE MILLING WASTE WATER:
OXIDATION OF PROTOCATECHUIC ACID \\ OXIDATION OF PROTOCATECHUIC ACID
}

I. Poulios*
D. Makri
X. Prohaska

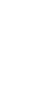

. 
ants. In addition the photocatalytic process is operated under mild conditions and as it can be powered by sunlight, has a reduced electric power requirements and operating costs (Gupta and Anderson, 1991; Goswami, 1995).

Olive oil is a typical Mediterranean product and its nutritional and economical importance is well known. The waste water from the olive oil milling (extraction) process (OMW) is highly pollutant due to the high organic carbon content, substantial portion of which is present as phenols, polyphenols, tannins, (Zouari and Ellouz, 1996). The pollution potential of OMW, expressed as Chemical Oxygen Demand (COD) concentration, varies from $100-250 \mathrm{~kg}$ $\mathrm{m}^{-3}$. OMW is a serious environmental problem, not only due to its high organic load and the presence of recalcitrant compounds with biostatic action, but also because it is produced in very high quantities during a short period of time.

Several chemical and biological procedures are increasingly used in order to transform OMW into more biodegradable residues, some with success, but they are not widely implemented due to their high installation and operation costs (Borja et al., 1992; Matzavinos et al., 1996; Benitez et al., 1997).

In the present study, results are provided for the photocatalytic oxidation and mineralization of protocatechuic acid, which is abundantly present in the OMW, over $\mathrm{TiO}_{2}$ and $\mathrm{ZnO}$ powders under various experimental conditions. Protocatechuic acid is a key polyphenolic pollutant and it belongs to a range of compounds together with gallic, gentistic, caffeic and p-coumaric acid, which are known to inhibit the biological treatment of wastewaters from agricultural origin.

In the recent literature some reports have dealt with the photodegradation of protocatechuic acid in the absence or presence of oxidants such as $\mathrm{O}_{3}$ and $\mathrm{H}_{2} \mathrm{O}_{2}$ (Benitez et al. 1993; Benitez et al., 1996), but nothing, as far as we know, has been reported about its photocatalytic destruction.

\section{EXPERIMENTAL}

Protocatechuic acid $\left(\mathrm{C}_{7} \mathrm{H}_{6} \mathrm{O}_{4}\right.$, 3,4-dihydroxybenzoic acid) of purum quality was a Fluka product and was used as received. Its structure is presented beside:
$\mathrm{TiO}_{2} \mathrm{P}-25$ from Degussa (anatase/rutile $=3.6 / 1$, surface area $56 \mathrm{~m}^{2} \mathrm{~g}^{-1}$, non-porous) was used for all photocatalytic experiments, except otherwise mentioned in the text. $\mathrm{TiO}_{2}-\mathrm{A}$ (pure anatase, $10 \mathrm{~m}^{2} \mathrm{~g}^{-1}$ ) and $\mathrm{ZnO}\left(10 \mathrm{~m}^{2} \mathrm{~g}^{-1}\right)$ were obtained from Merck.

Experiments were performed in an open thermostated Pyrex cell of $250 \mathrm{ml}$ capacity $(9 \mathrm{~cm}$ diameter, $3.5 \mathrm{~cm}$ height). The reaction mixture in the cell was maintained in suspension by magnetic stirring. The irradiation was carried out using four parallel $15 \mathrm{~W}$ blacklight blue fluorescent tubes mounted in standard $15 \mathrm{~W}$ fluorescent tube holders (Philips TLD 15W/08, $45 \mathrm{~cm}$ length, $2.6 \mathrm{~cm}$ diameter). According to the producer, each tube has a total radiative output of $2.2 \mathrm{~W}$, between $340-400 \mathrm{~nm}$ with maximum emission at $370 \mathrm{~nm}$.

In all cases, during the experiments, $200 \mathrm{ml}$ of the protocatechuic acid solution containing the appropriate quantity of the semiconductor powder were magnetically stirred before and during the illumination. At specific time intervals, samples of $5 \mathrm{ml}$ were withdrawn. To remove the $\mathrm{TiO}_{2}$ particles, the solution was filtered through a $0.45 \mu \mathrm{m}$ filter (Schleicher and Schuell). Changes in the concentration of protocatechuic acid were observed from its characteristic absorption at $290 \mathrm{~nm}$, using a UV-visible spectrophotometer (Shimadzu UV-160 A) or a high performance liquid chromatography system (Shimadzu LC 7A).

Experiments in the presence of sunlight were performed in July 1997, under the same conditions as those in the presence of artificial light, from 12 to 4 p.m. so that the irradiation was as intense as possible. Two series of experiments were carried out; one under abundant sunlight and the other under a cloudy sky.

In order to determine the $\mathrm{CO}_{2}$ release, a second apparatus was used. It consisted of a borosilicate glass vessel of $6 \mathrm{~cm}$ diameter and $13.5 \mathrm{~cm}$ height hermetically sealed with a silicone rubber. The reaction vessel was fitted with a central $11 \mathrm{~W}$ lamp (Osram Dulux S 11W/78) and had inlet and outlet ports for bubbling the selected gas, for each reaction. Formation of $\mathrm{CO}_{2}$ during the photooxidation in the reaction vessel, was followed by measurements of the conductivity increase of an ultra pure water, with the aid of a conductivity meter (Matthews et al. 1990). The $\mathrm{pH}$ value of the solutions was monitored by a Metrohm $\mathrm{pH}$-meter and the reaction temperature was kept constant at $25 \pm 0.1^{\circ} \mathrm{C}$. 


\section{RESULTS AND DISCUSSION Photodegradation experiments}

It is well established that by the irradiation of an aqueous $\mathrm{TiO}_{2}$ suspension with light energy greater than the band gap energy of the semiconductor $\left(\mathrm{hv}>\mathrm{Eg}=3.2 \mathrm{eV}\right.$ ), conduction band electrons $\left(\mathrm{e}^{-}\right)$and valence band holes $\left(\mathrm{h}^{+}\right)$are generated. After this primary event, part of the photogenerated carriers recombine in the bulk of the semiconductor with heat emission, while the rest reach the surface where the holes as well as the electrons act as powerful oxidants and reductants respectively. The photogenerated electrons react with the adsorbed molecular $\mathrm{O}_{2}$ on the Ti(III)-sites reducing it to superoxide radical anion $\mathrm{O}_{2}{ }^{--}$, while the photogenerated holes can oxidize either the organic molecules directly or the $\mathrm{OH}^{-}$ions and the $\mathrm{H}_{2} \mathrm{O}$ molecules adsorbed at the $\mathrm{TiO}_{2}$ surface to $\mathrm{OH}$ radicals (Fig. 1a). These together with other highly oxidant species (peroxide radicals) are responsible for the primary oxidizing step in photocatalysis, as reported by Pelizzetti and Minero, (1993). According to this, the relevant steps of the photodegradation process at the semiconductor surface can be summarized by the reactions in Fig. $1 b$.

The $\mathrm{OH}$ radicals formed on the illuminated semiconductor surface are very strong oxidizing agents with an oxidation potential of $2.8 \mathrm{~V}$. These can easily attack the adsorbed organic molecules or those located close to the surface of the catalyst, thus finally

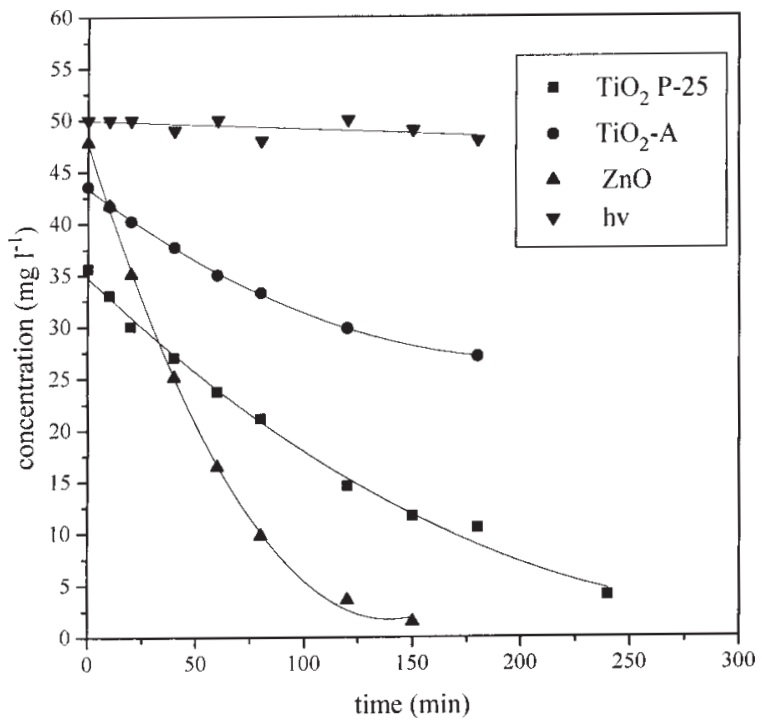

Figure 2. Photodegradation of $50 \mathrm{mg} \mathrm{l}^{-1}$ protocatechuic acid as a function of irradation time in the presence of ( 1 ) $1 \mathrm{~g} \mathrm{l}^{-1} \mathrm{TiO}_{2} \mathrm{P}-25$, (p) $1 \mathrm{~g} \mathrm{l}^{-1} \mathrm{ZnO}$, (ब) $1 \mathrm{~g} \mathrm{l}^{-1} \mathrm{TiO}_{2}-\mathrm{A}$ and (\&) without catalyst.

leading to their complete mineralization.

At first, experiments concerning the photocatalytic decomposition of $50 \mathrm{mg} \mathrm{l}^{-1}$ protocatechuic acid were performed, in the presence of semiconductor catalysts such as $\mathrm{TiO}_{2} \mathrm{P}-25, \mathrm{ZnO}$ and $\mathrm{TiO}_{2}$-A. Among these, $\mathrm{ZnO}$ and $\mathrm{TiO}_{2} \mathrm{P}-25$ produced the best results.

Results of the photolysis of a $50 \mathrm{mg} \mathrm{l}^{-1}$ protocatechuic acid solution containing $1 \mathrm{~g} \mathrm{l}^{-1} \mathrm{TiO}_{2} \mathrm{P}-25,1 \mathrm{~g} \mathrm{l}^{-1}$

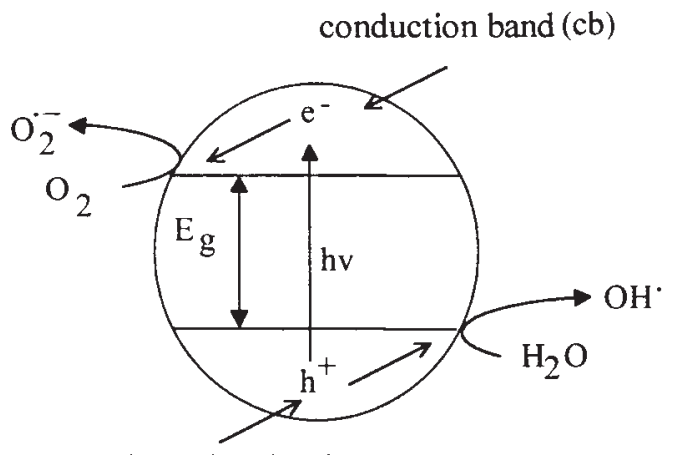

valence band $(\mathrm{vb})$

$$
\begin{aligned}
& \mathrm{TiO}_{2}+\mathrm{hv} \longrightarrow \mathrm{e}^{-}+\mathrm{h}^{+} \\
& \left(\mathrm{O}_{2}\right)_{\mathrm{ads}}+\mathrm{e}^{-} \longrightarrow \quad\left(\mathrm{O}_{2}^{--}\right) \text {ads } \\
& \mathrm{Ti}(\mathrm{IV})-\mathrm{OH}+\mathrm{h}^{+} \longrightarrow \mathrm{Ti}(\mathrm{IV}) \mathrm{OH} \cdot \\
& \mathrm{Ti}(\mathrm{IV})-\mathrm{H}_{2} \mathrm{O}+\mathrm{h}^{+} \longrightarrow \mathrm{Ti}(\mathrm{IV}) \mathrm{OH} \cdot+\mathrm{H}^{+}
\end{aligned}
$$$$
\mathrm{R}+\mathrm{h}^{+} \longrightarrow \mathrm{R} \text { (oxidized) }
$$

Figure 1. (a) $\mathrm{The}^{\mathrm{TiO}}$ /solution interface under UV- illumination (b) Reactions on the $\mathrm{TiO}_{2}$ surface under UV-illumination. 
$\mathrm{ZnO}$ or $1 \mathrm{~g} \mathrm{l}^{-1} \mathrm{TiO}_{2}$-A are shown in Fig. 2. The amount of the organic molecule present in the supernatant is plotted as a function of irradiation time. From Fig. 2, it is clear that the photolysis of an air equilibrated protocatechuic acid solution in the presence of the semiconducting catalysts could lead to the disappearance of the compound. Under these experimental conditions, in the presence of $\mathrm{TiO}_{2} \mathrm{P}-25$, around $80 \%$ of the initial concentration of the acid was removed after $3 \mathrm{~h}$ of light exposure, while for the same time interval and in the presence of $\mathrm{ZnO}$ the degradation was almost completed. Due to the photocorrosion presented by $\mathrm{ZnO}$, especially in low $\mathrm{pH}$ values and due to photostability and constant crystalline composition of anatase-based $\mathrm{TiO}_{2} \mathrm{P}-25$ powders on the other hand, this catalyst was used throughout the whole work. The decomposition of protocatechuic acid in the presence of $\mathrm{TiO}_{2}-\mathrm{A}$, as can be seen in Fig. 2, is a slower process and after $3 \mathrm{~h}$ of illumination more than $50 \%$ of the initial concentration remained in the solution. On the contrary, a very small decrease in the concentration of this compound was observed by illumination in the absence of any

Table 1. Initial reaction rates $\left(\mathrm{r}_{\mathrm{o}}\right)$ from the photodecomposition of $50 \mathrm{mg} . \mathrm{l}^{-1}$ protocatechuic acid under various experimental conditions.

\begin{tabular}{|c|c|c|}
\hline \multicolumn{2}{|c|}{$\begin{array}{l}\text { Experimental } \\
\text { Conditions }\end{array}$} & \multirow{2}{*}{$\begin{array}{c}\begin{array}{c}\text { initial } \\
\text { reaction } \\
\text { rate } \\
\left(\mathbf{m g ~ l}^{-\mathbf{1}} \mathbf{~ m i n}^{-1}\right)\end{array} \\
0.324 \pm 0.034 \\
\end{array}$} \\
\hline $\mathrm{TiO}_{2} \mathrm{P}-25$ & $\left(1 \mathrm{~g} \mathrm{l}^{-1}\right)$ & \\
\hline $\mathrm{ZnO}$ & $\left(1 \mathrm{~g} \mathrm{l}^{-1}\right)$ & $0.540 \pm 0.018$ \\
\hline $\mathrm{TiO}_{2}$ Merck & $\left(1 \mathrm{~g} \mathrm{l}^{-1}\right)$ & $0.196 \pm 0.009$ \\
\hline sunny day $(9$. & $\left.\mathrm{V} \mathrm{cm}^{-2}\right)^{*}$ & $0.637 \pm 0.086$ \\
\hline cloudy day (2 & $\left.\mathrm{W} \mathrm{cm}^{-2}\right)^{*}$ & $0.092 \pm 0.014$ \\
\hline
\end{tabular}

*in the presence of $1 \mathrm{~g} \mathrm{l}^{-1} \mathrm{TiO}_{2} \mathrm{P}-25$

catalyst (Fig. 2). After $3 \mathrm{~h}$ of irradiation with UV light (hv> $340 \mathrm{~nm}$ ), direct photolysis contributed less than $5 \%$ to the degradation of protocatechuic acid.

The influence of the initial concentration of the solute on the photocatalytic degradation rate of most of the organic compounds is described by a pseudofirst kinetic order, which is rationalized in terms of the Langmuir-Hinselwood model, modified to accommodate reactions occurring at a solid-liquid in- terface (Al-Ekabi and Serpone, 1988; Turchi and Ollis, 1990),

$$
\mathrm{r}=-\frac{\mathrm{dC}}{\mathrm{dt}}=\frac{\mathrm{k}_{\mathrm{r}} \mathrm{KC}}{1+\mathrm{KC}}
$$

where $r$ is the rate of disappearance of the organic substrate and $\mathrm{C}$ is its concentration. $\mathrm{K}$ represents the equilibrium constant for adsorption of the organic substrate onto $\mathrm{TiO}_{2}$ and $\mathrm{k}_{\mathrm{r}}$ reflects the limiting rate of reaction at maximum coverage for the experimental conditions.

In Table 1 the initial reaction rate $\left(\mathrm{r}_{\mathrm{o}}\right)$ values from the photodecomposition of the above compound under various experimental conditions are presented. The $r_{o}$ values were independently obtained by polynomial fitting of the concentration data (with respect to time) for the first 40 minutes of the reaction, Figs. 2 and 5. Due to the fact that protocatechuic acid is adsorbed particularly strongly on the $\mathrm{TiO}_{2}$ surface, the equilibrium concentration instead of the initial one has been used in the kinetic study (Cunningham et al., 1994). It must be pointed out that the comparison of the $r_{\mathrm{o}}$-values of the three oxides, under the given experimental conditions, is of a more or less qualitative character. Their different physicochemical characteristics (BET, extend of adsorption, etc.) do not allow absolute conclusions as regards the comparison of their photocatalytic activities.

\section{Effect of oxidants}

The addition of other powerful oxidizing species such as $\mathrm{H}_{2} \mathrm{O}_{2}$ or $\mathrm{K}_{2} \mathrm{~S}_{2} \mathrm{O}_{8}$ to $\mathrm{TiO}_{2}$ suspensions is a well known procedure and in many cases leads to an increase of the rate of photooxidation (Graetzel et al., 1990; Pelizzetti et al., 1991). $\mathrm{H}_{2} \mathrm{O}_{2}$ is considered to have two functions in the process of photocatalytic degradation. It accepts a photogenerated electron from the conduction band and thus promotes the charge separation (eq. 2). It also forms $\mathrm{OH}$ radicals according to eq. 3 .

$$
\begin{aligned}
& \mathrm{H}_{2} \mathrm{O}_{2}+\mathrm{e}^{-} \longrightarrow \mathrm{OH}^{-}+\mathrm{OH}^{-} \\
& \mathrm{H}_{2} \mathrm{O}_{2}+\mathrm{O}_{2} \longrightarrow \mathrm{OH}+\mathrm{OH}^{-}+\mathrm{O}_{2}
\end{aligned}
$$

In our case the photocatalytic degradation of 50 $\mathrm{mg} \mathrm{l}^{-1}$ protocatechuic acid has been studied at different $\mathrm{H}_{2} \mathrm{O}_{2}$ concentrations. The effect of the amount of $\mathrm{H}_{2} \mathrm{O}_{2}$ on the initial reaction rate is shown in Fig. 3. The photocatalytic efficiency increases when the 


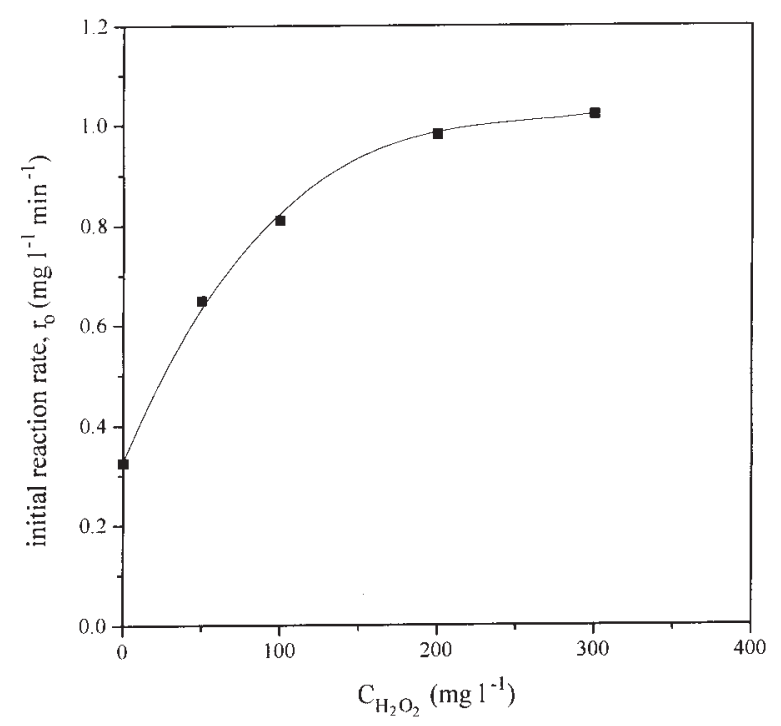

Figure 3. Effect of the $\mathrm{H}_{2} \mathrm{O}_{2}$ concentration on the photodegradation of $50 \mathrm{mg} \mathrm{l}^{-1}$ protocatechuic acid in the presence of $1 \mathrm{~g} \mathrm{l}^{-1} \mathrm{TiO}_{2} \mathrm{P}-25$.

concentration of $\mathrm{H}_{2} \mathrm{O}_{2}$ increases and reaches a maximum in the region of 200-300 $\mathrm{mg} \mathrm{l}^{-1}$. Beyond this maximum, the photocatalytic efficiency starts decreasing. It is well known that $\mathrm{H}_{2} \mathrm{O}_{2}$ may act as a hole or $\mathrm{OH}$ scanvenger or react with $\mathrm{TiO}_{2}$ and form peroxo compounds, which are detrimental to the photocatalytic action. This explains the need for an optimal concentration of $\mathrm{H}_{2} \mathrm{O}_{2}$ for the maximum effect. Under these conditions, the addition of 200 $\mathrm{mg} \mathrm{l}^{-1} \mathrm{H}_{2} \mathrm{O}_{2}$ accelerates the degradation by a factor of 4.3. This positive effect is comparable to the one observed during photooxidation in other cases (Wolfrum and Ollis, 1994).

\section{Photomineralization experiments}

As mentioned above, the complete decomposition of organic compounds to $\mathrm{CO}_{2}$ via photocatalytic reactions is of great significance in water treatment, because it is the unequivocal evidence for their total destruction of organic compounds in water. For this reason, the conversion of protocatechuic acid to $\mathrm{CO}_{2}$ was studied in a separate apparatus described in the experimental section.

The overall equation, valid after long irradiation time in the presence of excess oxygen, which describes the photocatalytic mineralization of protocatechuic acid is presented below:

$\mathrm{C}_{7} \mathrm{H}_{6} \mathrm{O}_{4}+17 / 2 \mathrm{O}_{2} \rightarrow$ intermediates $\rightarrow 7 \mathrm{CO}_{2}+3 \mathrm{H}_{2} \mathrm{O}$

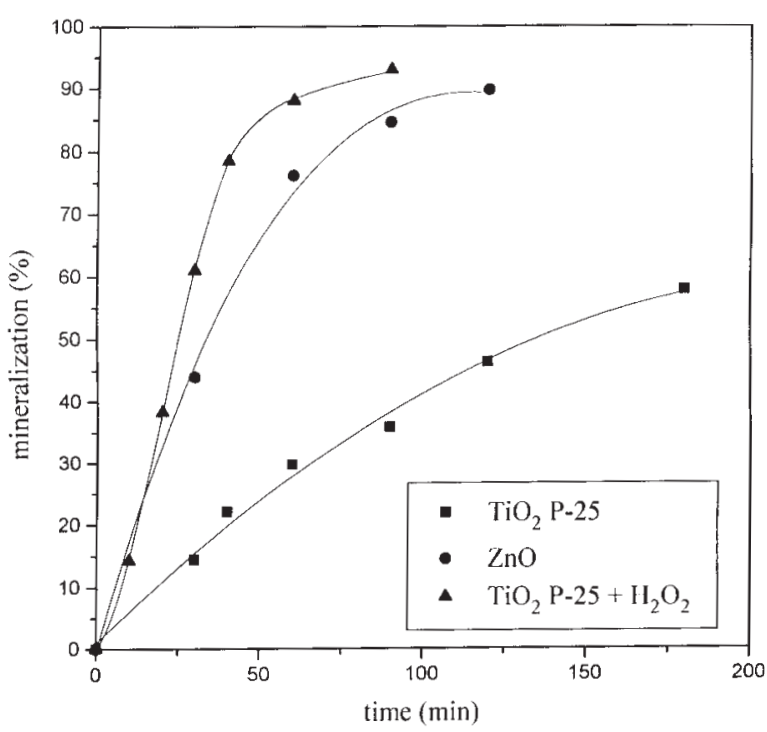

Figure 4. $\mathrm{CO}_{2}$ formation as a function of irradiation time during the photocatalytic degradation of $50 \mathrm{mg} \mathrm{l}^{-1}$ protocatechuic acid in the presence of $1 \mathrm{~g} \mathrm{l}^{-1}$ $\mathrm{TiO}_{2}-\mathrm{P} 25$ (ם), $1 \mathrm{~g} \mathrm{l}^{-1} \mathrm{TiO}_{2} \mathrm{P}-25+200 \mathrm{mg} \mathrm{l}^{-1}$ $\mathrm{H}_{2} \mathrm{O}_{2}(\mathrm{p}), 1 \mathrm{~g} \mathrm{l}^{-1} \mathrm{ZnO}(\bullet)$,

Fig. 4 shows the formation of $\mathrm{CO}_{2}$ vs. illumination time of a solution containing $50 \mathrm{mg} \mathrm{l}^{-1}$ protocatechuic acid in the presence of $\mathrm{TiO}_{2} \mathrm{P}-25, \mathrm{ZnO}$ or $\mathrm{TiO}_{2} \mathrm{P}-25+200 \mathrm{mg} \mathrm{l}^{-1} \mathrm{H}_{2} \mathrm{O}_{2}$. The concentration of $200 \mathrm{mg} \mathrm{l}^{-1} \mathrm{H}_{2} \mathrm{O}_{2}$, according to Fig. 3 , is the one with the greater influence on the acceleration of the photodegradation of protocatechuic acid.

In the presence of $\mathrm{TiO}_{2} \mathrm{P}-25$, only $58 \%$ of protocatechuic acid was converted to $\mathrm{CO}_{2}$ in the first $3 \mathrm{~h}$ of illumination, while $80 \%$ (Fig. 2) was decomposed in the same time showing the presence of intermediates. Full oxidation requires longer irradiaton time. The addition of $200 \mathrm{mg} \mathrm{l}^{-1} \mathrm{H}_{2} \mathrm{O}_{2}$ in a suspension of $\mathrm{TiO}_{2}$ P-25/protocatechuic acid, as shown in Fig. 4, alters significantly the photomineralization process and in the first one and half hour, $90 \%$ of the parent compound was converted to $\mathrm{CO}_{2}$. This is also in agreement with the results depicted in Fig. 3, where the degradation rates in the presence of various concentrations of $\mathrm{H}_{2} \mathrm{O}_{2}$ are shown.

As can also be seen in Fig. 4, in the presence of $\mathrm{ZnO}$, the mineralization process under the given experimental conditions is faster compared to that in the presence of $\mathrm{TiO}_{2} \mathrm{P}-25$. From Figs. 2 and 4, it is clear that in the case of $\mathrm{ZnO}$, the reaction rate of the degradation, as well as the mineralization, is higher than the corresponding of $\mathrm{TiO}_{2}$. This fact could be 
explained as a result of the generation of $\mathrm{H}_{2} \mathrm{O}_{2}$ on the $\mathrm{ZnO}$ surface, due to the reaction of the photogenerated electrons in conduction band with the adsorbed $\mathrm{O}_{2}$ molecules, leading thus to an increase of the initial rate of mineralization. According to Kormann et al. (1988), the quantum yield of $\mathrm{H}_{2} \mathrm{O}_{2}$ production in illuminated aqueous suspensions of $\mathrm{ZnO}$ was found to be one order of magnitude higher than the corresponding value for $\mathrm{TiO}_{2}$ (Kormann et al., 1988; Hoffman et al., 1994).

In the case of $\mathrm{TiO}_{2}$ - $\mathrm{A}$ the photomineralization proceeds with lower efficiency compared to the one when $\mathrm{TiO}_{2} \mathrm{P}-25$ or $\mathrm{ZnO}$ has been used and after $3 \mathrm{~h}$ of illumination only $44 \%$ of the initial carbon content has been converted to $\mathrm{CO}_{2}$.

The better performance of $\mathrm{TiO}_{2} \mathrm{P}-25$ may be attributed to the morphology of crystallites, which was proposed to be one of the most critical properties for the photocatalytic efficiency of $\mathrm{P}-25$, among various grades of $\mathrm{TiO}_{2}$. Crystallographic study shows that it consists of multiphases of amorphous, anatase and rutile forms. The close proximity of these phases and in some cases the overlapping of forms has been cited to be the reason for long lasting excitation of electrons from the valence to the conductive bands, allowing for efficient and effective degradation of organic compounds (Nargiello et al., 1993).

The photocatalytic degradation of protocatechuic acid is a complicated process with a mechanism involving several chemical and photocatalytic stages and a great number of intermediates. The details of the mechanism are not yet entirely clear. On the basis of our preliminary experimental results and some pertinent suggestions of other researchers concerning the photodecomposition of various carboxylic acids (Trillas et al. 1993; Tunesi and Anderson 1991; Sun and Pignatello 1995), the dual hole-radical mechanism may be proposed for the protocatechuic acid photooxidation, in which direct $\mathrm{h}^{+}$oxidation of the carboxylic group takes place under $\mathrm{CO}_{2}$ liberation, in competition with the $\mathrm{OH} \cdot$ attack of the aromatic ring. In the latter case, the resulting $\mathrm{OH}$ adduct is finally decomposed and, as a result of the ring opening, the formation of carbonyl compounds and carboxylic acids takes place. Irradiation of the suspension for longer time leads, according to eq. (4), to complete conversion of the parent compound, as well as of the intermediate products to $\mathrm{CO}_{2}$ (Pelizzetti et al., 1993).

\section{Solar and biodegradability experiments}

For the solar exposure experiments the same open Pyrex cell, as for the previous measurements under artificial light, is adapted. The photodegradation of protocatechuic acid under solar illumination on a sunny day $\left(9.5 \mathrm{~mW} \mathrm{~cm}^{-2}\right)$ and on a cloudy day $\left(2.1 \mathrm{~mW} \mathrm{~cm}^{-2}\right)$ is shown in Fig. 5. In the same figure the photodegradation under artificial irradiation is also presented. The time required for a $50 \%$ degradation of $50 \mathrm{mg} \mathrm{l}^{-1}$ protocatechuic acid, under the given experimental conditions, was $26 \mathrm{~min}$ in the case of the sunny day, approximately 2 times faster than with the blacklight fluorescent tubes and more than 2.5 times slower in the case of the cloudy day. Consequently, protocatechuic acid can be effectively degraded in $\mathrm{TiO}_{2}$ suspension under solar exposure.

Finally, some preliminary experiments concerning the biodegradability of this compound were carried out. The Biochemical Oxygen Demand in 5 days $\left(\mathrm{BOD}_{5}\right)$ of a $50 \mathrm{mg} \mathrm{l}^{-1}$ protocatechuic acid solution was measured before and after the photocatalytic oxidation. From the results in Table 2 it is clear that after the photocatalytic pretreatment protocatechuic acid, a non biodegradable compound, is converted into intermediates and/or end products, which can be more readily attacked by the microorganisms. The aromatic ring cleavage and the appearance of the aliphatic products, which are more biodegradable, is responsible for this behaviour.

\section{CONCLUSIONS}

This study presents results of the photocatalytic oxidative degradation of protocatechuic acid, a biorecalcitrant polyphenolic compound typically found in olive processing and wine distillery waste waters. It was observed that, $\mathrm{ZnO}$ is more efficient as a photocatalyst, both in respect of degradation as well as mineralization. Due to the photocorrosion presented by $\mathrm{ZnO}$, especially in low $\mathrm{pH}$ on the one, and due to photostability and constant crystalline composition of anatase-based $\mathrm{TiO}_{2} \mathrm{P}-25$ powders on the other hand, this catalyst was used throughout the work. The combination of the catalysts with $\mathrm{H}_{2} \mathrm{O}_{2}$ leads to an increase of the photooxidation rates, due to the higher concentration of the hydroxyl radicals generated from the synergetic effect of the semiconductor with the hydrogen peroxide.

The results from the biodegradability experi- 


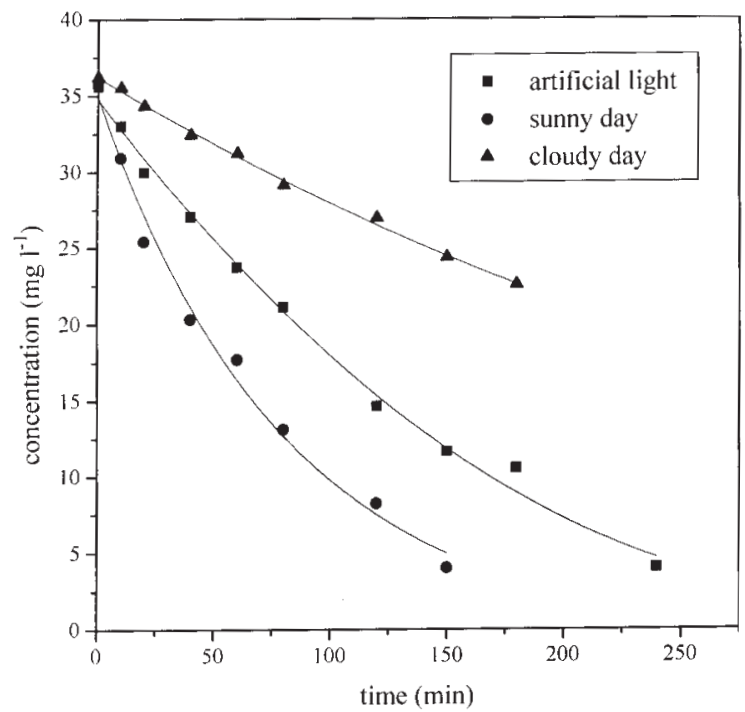

Figure 5. Photocatalytic degradation of $50 \mathrm{mg} \mathrm{l}^{-1}$ protocatechuic acid under artificial and natural illumination in the presence of $1 \mathrm{~g} \mathrm{l}^{-1} \mathrm{TiO}_{2} \mathrm{P}-25$.
Table 2. $\mathrm{BOD}_{5}$ of $50 \mathrm{ppm}$ protocatechuic acid before and after photocatalytic treatment*

\begin{tabular}{|c|c|}
\hline $\begin{array}{c}\text { Photocatalytic } \\
\text { pre-treatment }(\mathbf{h})\end{array}$ & BOD5 $\left(\mathbf{m g ~ l}^{-\mathbf{1}}\right)$ \\
\hline 0 & 0 \\
\hline 1 & $4.5 \pm 0.37$ \\
\hline 3 & $10.3 \pm 0.85$ \\
\hline
\end{tabular}

*in the presence of $1 \mathrm{~g} \mathrm{l}^{-1} \mathrm{TiO}_{2} \mathrm{P}-25$

ments had shown, that protocatechuic acid after the photocatalytic treatment is converted into compounds, which can be more readily attacked by the microorganisms. An integrated photocatalyticbiological system, under solar exposure, for the destruction of biorecalcitrant polyphenolic compounds, seems a logical choice for the treatment of waste waters such as from the olive milling process.

\section{REFERENCES}

Al-Ekabi, H. and Serpone, N. (1988). Kinetic-studies in heterogeneous photocatalysis .1.Photocatalytic degradation of chlorinated phenols in aerated aqueous-solutions over $\mathrm{TiO}_{2}$ supported on a glass matrix. J. Phys. Chem. 92, 5726-5731.

Benitez, F. J., Beltran-Heredia, J., Acero, J. and Conzalez, T. (1993). Photochemical oxydation of protocatechuic acid. Wat. Res. 28, 2095-2100.

Benitez, F. J., Beltran-Heredia, J., Acero, J. and Conzalez, T. (1996). Degradation of protocatechuic acid by two advanced oxydation processes: Ozone/UV radiation and $\mathrm{H}_{2} \mathrm{O}_{2} / \mathrm{UV}$ radiation. Wat. Res. 30, 1597-1604.

Benitez, F. J., Beltran-Heredia, J., Acero, J. and Pinilla, M. (1997). Simultaneous photodegradation and ozonation plus UV radiation of phenolic acids-Major pollutants in agro-industrial waste waters. J. Chem. Technol. and Biotechnol. 70, 253-260.

Borja R., Martin, A, Alba, J and Fiestas, J.A. (1992). Enhancement of the anaerobic digestion of olive mill wastewater by the removal of phenolic inhibitors. Process Biochem.27, 231-237.

Cunningham, J., Al-Sayyed, G. and Srijaranai, S.(1994). Adsorption of model pollutants onto $\mathrm{TiO}_{2}$ particles in relation to photoremedation of contaminated water. Aquatic and Surface Photochemistry (eds., G. Helz, R. Zepp and D. Crosby), Chap. 22, Lewis Publs., CRC Press, 317-348.

Goswami D.Y. (1995). Engineering of the Solar Photocatalytic Detoxification and Desinfection Processes. Advances in Solar Energy (ed. K.W. Boer), Vol. 10, American Solar Energy Society Inc., Boulder, Colorado, 165-209.

Graetzel, G., Jirousek, J and Graetzel, M. (1990). Decomposition of organophosphorus compounds on photoactivated $\mathrm{TiO}_{2}$ surfaces. J. Molecular Catalysis 60, 375-387.

Gupta, B.P. and Anderson, J. (1991). Solar detoxification of hazardous waste - An overview of the United-StatesDepartment of Energy Program. Solar Energy Materials 24, 40-61.

Hoffman, A. J., Carraway, E. R. and Hoffman, M. R. (1994). Photocatalytic production of $\mathrm{H}_{2} \mathrm{O}_{2}$ and organic peroxides on quantum-sized semiconductor colloids. Env. Sci. Technol. 28, 776-785.

Hoffman, M. R, Martin, S., Choi, W. and Bahnemann, D. W. (1995). Environmental applications of semiconductor photocatalysis. Chem. Rev. 95, 69-96.

Kormann, C., Bahnemann, D. W. and Hoffman, M. R. (1988). Photocatalytic production of $\mathrm{H}_{2} \mathrm{O}_{2}$ and organic peroxides in aqueous suspensions of $\mathrm{TiO}_{2}, \mathrm{ZnO}$ and desert sand. Env. Sci. Technol. 22, 798-806.

Matthews, R. W., Abdullah, M. and Low, G. K. (1990). Photocatalytic oxidation for total organic carbon analysis. Anal. Chim. Acta 233, 171-179. 
Matzavinos, D., Hellenbrand, R., Metcalf, I. S. and Livingston, A.G. (1996). Partial wet oxidation of p-coumaric acid: Partial oxidation intermediates, reaction pathways and implications for waste water treatment. Wat. Res. 30, 2969-2976.

Nargiello, M. and Herz, T. (1993). Physical-chemical characteristics of P-25 making it extremely suited as the catalyst in photodegradation of organic compounds. Proc. $1^{\text {st }}$ Int. Conf. on TiO 2 Photocatalytic Purification and Treatment of Water and Air (eds. D.Ollis and H. Al-Ekabi), Amsterdam, Elsevier, 801.

Ollis, D., Pelizzetti, E. and Serpone, N. (1991). Photocatalysed destruction of water contaminants. Environ. Sci.Technol. 25, 1522-1529.

Pelizzetti, E., Carlin, V., Minero, C. and Graetzel, M. (1991). Enhancement of the rate of photocatalytic degradation on $\mathrm{TiO}_{2}$ of 2-chlorophenol, 2,7-dichlorodibenodioxin and atrazine by inorganic oxidizing species. New J. Chem. 15, 351-59.

Pelizzetti, E. and Minero, C. (1993). Mechanism of the photooxidative degradation of organic pollutants over $\mathrm{TiO}_{2}$ particles. Electrochim. Acta 38, 47-55.

Peral, J., Domenech, X. and Ollis, D. F. (1997). Heterogeneous photocatalysis for purification, decontamination and deodorization of air. J. Chem. Technol. and Biotechnol. 70, 117-140.

Sun, Y. and Pignatello, J. (1995). Evidence for a surface dual hole-radical mechanism in the $\mathrm{TiO}_{2}$ photocatalytic oxidation of 2,4-dichlorophenoxyacetic acid. Environ. Sci. Technol. 29, 2065-2072.

Trillas, M., Peral, J., Domenech, X. (1993). Photooxidation of phenoxyacetic acid by $\mathrm{TiO}_{2}$-illuminated catalyst. Appl. Catal. B: Environmental 3, 45-53.

Tunesi, S. and Anderson, M. (1991). Influence of chemisorption on the photodecomposition of salicylic acid and related compounds using suspended $\mathrm{TiO}_{2}$ ceramic membranes. J. Phys. Chem. 95, 3399-3405.

Turchi, C. S. and Ollis, D. F.(1990). Photocatalytic degradation of organic contaminants: mechanisms involving hydroxyl attack. J. Catal. 122, 178-92.

Wolfrum, E. J. and Ollis, D. F., (1994). Hydrogen Peroxide in Heterogeneous Photocatalysis. Aquatic and Surface Photochemistry (eds., G. Helz, R. Zepp and D. Crosby), Chap. 32, Lewis Publs., CRC Press, 451-465.

Zouari, N. and Ellouz, R. (1996). Toxic effect of coloured olive compounds on the anaerobic digestion of olive oil mill effluents in UASB-like reactors. J. Chem. Tech. Biotechnol. 66, 414-420. 